\title{
Front Matter: Volume 6585
}

, "Front Matter: Volume 6585," Proc. SPIE 6585, Optical Sensing Technology and Applications, 658501 (1 June 2007); doi: 10.1117/12.746931

SDIE Event: International Congress on Optics and Optoelectronics, 2007, Prague, SPIE. Czech Republic 


\title{
PROCEEDINGS OF SPIE
}

\section{Optical Sensing Technology and Applications}

\author{
Francesco Baldini \\ Jiri Homola \\ Robert A. Lieberman \\ Miroslav Miler \\ Editors
}

16-18 April 2007

Prague, Czech Republic

Sponsored by

SPIE Europe

Cooperating Organizations

SPIE Czech Republic Chapter

COST

ESF-European Science Foundation (France)

Czech and Slovak Society for Photonics

ePIXnet (Belgium)

Fyzikálni Ústav (Czech Republic)

Meta Morphose (United Kingdom)

NEMO-Network of Excellence in Micro-Optics (Belgium)

PhOREMOST

SPIE Poland Chapter

Published by

SPIE 
The papers included in this volume were part of the technical conference cited on the cover and title page. Papers were selected and subject to review by the editors and conference program committee. Some conference presentations may not be available for publication. The papers published in these proceedings reflect the work and thoughts of the authors and are published herein as submitted. The publisher is not responsible for the validity of the information or for any outcomes resulting from reliance thereon.

Please use the following format to cite material from this book:

Author(s), "Title of Paper," in Optical Sensing Technology and Applications, edited by Francesco Baldini, Jiri Homola, Robert A. Lieberman, Miroslav Miler, Proceedings of SPIE Vol. 6585 (SPIE, Bellingham, WA, 2007) Article CID Number.

ISSN 0277-786X

ISBN 9780819467133

Published by

SPIE-The International Society for Optical Engineering

P.O. Box 10, Bellingham, Washington 98227-0010 USA

Telephone 1 360/676-3290 (Pacific Time) · Fax 1 360/647-1445

http://www.spie.org

Copyright (C) 2007, The Society of Photo-Optical Instrumentation Engineers

Copying of material in this book for internal or personal use, or for the internal or personal use of specific clients, beyond the fair use provisions granted by the U.S. Copyright Law is authorized by SPIE subject to payment of copying fees. The Transactional Reporting Service base fee for this volume is $\$ 18.00$ per article (or portion thereof), which should be paid directly to the Copyright Clearance Center (CCC), 222 Rosewood Drive, Danvers, MA 01923. Payment may also be made electronically through CCC Online at http://www.copyright.com. Other copying for republication, resale, advertising or promotion, or any form of systematic or multiple reproduction of any material in this book is prohibited except with permission in writing from the publisher. The CCC fee code is 0277 $786 \times / 07 / \$ 18.00$.

Printed in the United States of America.

Publication of record for individual papers is online in the SPIE Digital Library.

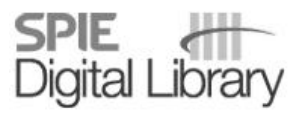

SPIEDigitalLibrary.org

Pagination: Proceedings of SPIE follow an e-First publication model, with papers published first online and then in print and on CD-ROM. Papers are published as they are submitted and meet publication criteria. A unique, consistent, permanent citation identifier (CID) number is assigned to each article at the time of the first publication. Utilization of CIDs allows articles to be fully citable as soon they are published online, and connects the same identifier to all online, print, and electronic versions of the publication. SPIE uses a six-digit CID article numbering system in which:

- The first four digits correspond to the SPIE volume number.

- The last two digits indicate publication order within the volume using a Base 36 numbering system employing both numerals and letters. These two-number sets start with 00, 01, 02, 03, 04, 05, 06, 07 , $08,09,0 A, O B \ldots 0 Z$, followed by 10-1Z, 20-2Z, etc.

The CID number appears on each page of the manuscript. The complete citation is used on the first page, and an abbreviated version on subsequent pages. 


\section{Contents}

Liquid crystalline nonlinear optical metamaterials with low-loss tunable negative-zeropositive refractive indices (Plenary Paper) [6587-203]

I. C. Khoo, A. Diaz, D.-H. Kwon, D. H. Werner, Pennsylvania State Univ. (USA)

\section{SESSION 1 COMPONENTS FOR SENSOR SYSTEMS I}

658502 Design of micro-ring optical sensors and circuits for integration on optical printed circuit boards (O-PCBs) (Invited Paper) [6585-01]

E.-H. Lee, H. S. Lee, S. G. Lee, B. H. O, S. G. Park, K. H. Kim, Inha Univ. (South Korea)

658503 Injection moulding integration of a red VCSEL illuminator module for a hologram reader sensor [6585-02]

K. Keränen, VTT (Finland); T. Saastamoinen, Univ. of JoensUu (Finland); J.-T. Mäkinen, VTT (Finland); M. Silvennoinen, Perlos (Finland); I. Mustonen, P. Vahimaa, T. Jääskeläinen, Univ. of JoensuU (Finland); A. Lehto, Helsinki Univ. of Technology (Finland); A. Ojapalo, Perlos (Finland); M. Schorpp, Nokia Corp. (Finland); P. Hoskio, Electroplast (Finland); P. Karioja, VTT (Finland)

658504 InAs and InAs(Sb)(P) (3-5 $\mu \mathrm{m})$ immersion lens photodiodes for portable optic sensors [6585-03]

M. A. Remennyy, B. A. Matveev, N. V. Zotova, S. A. Karandashev, N. M. Stus, N. D. llinskaya, loffe Physico-Technical Institute (Russia)

$658505 \quad \mathrm{Al}_{\mathbf{x}} \mathrm{Ga}_{1-\mathrm{x}} \mathbf{N}$ focal plane arrays for imaging applications in the extreme ultraviolet (EUV) wavelength range [6585-04]

J. John, IMEC (Belgium); P. Malinowski, P. Aparicio, G. Hellings, A. Lorenz, Catholic Univ. of Leuven (Belgium); M. Germain, IMEC (Belgium); F. Semond, J.-Y. Duboz, CRHEA, CEA (France); A. BenMoussa, J.-F. Hochedez, Royal Observatory of Belgium (Belgium); U. Kroth, M. Richter, Physikalisch-Technische Bundesanstalt (Germany)

658506 Low temperature co-fired ceramics on optoelectronic sensors integration [6585-05] V. Moilanen, K. Kautio, P. Karioja, VTT (Finland); R. Rikola, Rikola Ltd. (Finland); J. Lehtomaa, Specim Ltd. (Finland); J. Malinen, VTT (Finland)

\section{SESSION 2 COMPONENTS FOR SENSOR SYSTEMS II}

658507 Inmould integration of a microscope add-on system to a 1.3 Mpix camera phone [6585-06] J.-T. Mäkinen, K. Keränen, VTT-Technical Research Ctr. of Finland (Finland); J. Hakkarainen, Tampere Univ. of Technology (Finland); M. Silvennoinen, Perlos Corp. (Finland); T. Salmi, VTT-Technical Research Ctr. of Finland (Finland); S. Syrjälä, Tampere Univ. of Technology (Finland); A. Ojapalo, Perlos Corp. (Finland); M. Schorpp, Nokia Research Ctr. (Finland); P. Hoskio, Electroplast Oy (Finland); P. Karioja, VTT-Technical Research Ctr. of Finland (Finland) 
658508 Flat Fiber: the flexible format for distributed lab-on-a-chip [6585-07]

C. B. E. Gawith, A. S. Webb, R. J. Standish, J. K. Sahu, F. R. M. Adikan, J. C. Gates,

P. G. R. Smith, Univ. of Southampton (United Kingdom)

658509 Resolution of ratiometric system for wavelength measurement [6585-08]

Q. Wang, G. Rajan, P. Wang, G. Farrell, Dublin Institute of Technology (Ireland)

65850A Improved miniature wavelength meter based on polarisation state measurements [6585-09]

K. Ouedraogo, S. Topsu, L. Chassagne, J. Nasser, Y. Alayli, Univ. of Versailles (France)

SESSION 3 FIBRE OPTIC SENSORS I

65850B Nanostructure-based optical fibre sensor systems and examples of their application (Invited Paper) [6585-10]

R. Willsch, W. Ecke, G. Schwotzer, H. Bartelt, Institute of Photonic Technology (Germany)

65850C Transverse force sensor exploiting the birefringence effect in uniform fibre Bragg gratings [6585-11]

C. Caucheteur, S. Bette, Faculté Polytechnique de Mons (Belgium); R. Garcia-Olcina, Univ. Politècnica de València (Spain); M. Wuilpart, Faculté Polytechnique de Mons (Belgium);

S. Sales, J. Capmany, Univ. Politècnica de València (Spain); P. Mégret, Faculté

Polytechnique de Mons (Belgium)

65850D Continuous monitoring of setting and hardening of mortar using FBG sensors [6585-12]

H. Lima, Univ. de Aveiro (Portugal); R. Ribeiro, Saint-Gobain Weber Cimenfix (Portugal);

R. Nogueira, Instituto de Telecomunicações (Portugal); L. Silva, Saint-Gobain Weber Cimenfix (Portugal); I. Abe, Univ. de Aveiro (Portugal); J. L. Pinto, Univ. de Aveiro (Portugal) and Instituto de Telecomunicações (Portugal)

65850E Feasibility study of an embedded multi-axial fibre Bragg grating sensor [6585-14]

G. Luyckx, W. De Waele, J. Degrieck, W. Van Paepegem, Ghent Univ. (Belgium); J. Vlekken, T. Verbeke, Fos\&s (Belgium)

$65850 \mathrm{~F}$ Long-period gratings with high insensitivity to external refractive index inscribed by using a $\mathrm{CO}_{2}$ laser in fibers with parabolic-index cladding [6585-15]

M. Chomát, J. Čtyroký, D. Berková, V. Matějec, I. Kašík, J. Proboštová, Institute of Photonics and Electronics (Czech Republic); F. Todorov, Institute of Photonics and Electronics (Czech Republic) and Czech Technical Univ. in Prague (Czech Republic); A. Jančárek, Czech Technical Univ. in Prague (Czech Republic)

\section{SESSION 4 FIBRE OPTIC SENSORS II}

$65850 \mathrm{H}$ Multiparameter modular optical fiber sensor for applications in oil refinery [6585-17]

T. R. Woliński, A. W. Domański, D. Budaszewski, S. Ertman, Warsaw Univ. of Technology (Poland)

65850l An optical fiber Bragg grating tactile sensor [6585-18]

B. Cowie, T. Allsop, J. Williams, D. Webb, I. Bennion, Aston Univ. (United Kingdom); M. Fisher, Aerovac Systems Ltd. (United Kingdom) 
65850J Wireless temperature sensors using single crystal silicon carbide: an industrial feasibility and design study [6585-19]

N. A. Riza, Nuonics, Inc. (USA) and College of Optics and Photonics, Univ. of Central Florida (USA); M. Sheikh, College of Optics and Photonics, Univ. of Central Florida (USA); F. Perez, Nuonics, Inc. (USA)

\section{SESSION $5 \quad$ INTERFEROMETRIC SENSORS}

65850K Novel concept of interferometric control of the moving coil in watt balance [6585-20] M. Wakim, Univ. of Versailles (France) and LNE (France); L. Chassagne, S. Topsu, Y. Alayli, Univ. of Versailles (France); J. P. Wallerand, P. Juncar, LNE-INM (France); G. Geneves, LNE (France)

65850L Fabrication and test of an integrated optical sensor with high sensitivity and high dynamic range based on a Mach-Zehnder interferometric configuration [6585-22]

D. Alexandre, UOSE, INESC-Porto (Portugal), Univ. do Porto (Portugal), and Univ. de Trás-osMontes e Alto-Douro (Portugal); J. Viegas, L. Fernandes, P. J. Moreira, UOSE, INESC-Porto (Portugal) and Univ. do Porto (Portugal); A. M. P. Leite, Univ. do Porto (Portugal); J. L. Santos, P. Marques, UOSE, INESC-Porto (Portugal) and Univ. do Porto (Portugal)

SESSION 6 INTEGRATED OPTICAL SENSORS

65850N An optical microsystem based on vertical silicon-air Bragg mirror for liquid substances monitoring [6585-24]

L. De Stefano, I. Rendina, IMM-CNR (Italy); I. Rea, L. Rotiroti, IMM-CNR (Italy) and Federico II Univ. of Naples (Italy); E. De Tommasi, IMM-CNR (Italy); G. Barillaro, Univ. Pisa (Italy)

658500 New geometry for planar UV written refractive index sensors [6585-25]

J. C. Gates, C. H. Holmes, F. R. M. Adikan, C. B. E. Gawith, P. G. R. Smith, Univ. of Southampton (United Kingdom)

65850P Design of nonlinear optical waveguide sensors with metallic cores by uniform field profile approach [6585-26]

M. M. Abadla, Alaqsa Univ. (Palestinian Authority); M. M. Shabat, Max-Planck-Institut für Physik komplexer Systeme (Germany)

65850Q Interrogation of multiplexed FBG sensors with a strain tuned EDF laser using a high-strength grating [6585-28]

A. S. Paterno, N. Haramoni, J. C. C. Silva, F. Kuller, Federal Univ. of Technology, Paraná (Brazil); H. J. Kalinowski, Federal Univ. of Technology, Paraná (Brazil) and Institute of Telecommunications, Univ. of Aveiro (Portugal)

65850R Fiber optical sensor network embedded in a current collector for defect monitoring on railway catenary [6585-29]

K. Schröder, W. Ecke, M. Kautz, Institute of Photonic Technology (Germany); S. Willett, Morganite Electrical Carbon Ltd. (United Kingdom); A. Tchertoriski, IRE Ulyanovsk (Russia); M. Jenzer, BLS AG (Switzerland); G. Kaluza, ARGE X (Austria) 
65850 Imaging spectral signature satellite instrument for the real-time identification of ground scenes with a dedicated spectral signature [6585-31]

U. Kantojärvi, H. Saari, K. Viherkanto, VTT (Finland); E. Herrala, Specim (Finland); B. Harnisch, European Space Agency (Netherlands)

65850T New compact rotationally symmetric triangulation sensor with low-cost plastic optics [6585-32]

J. Eckstein, Univ. of Technology, Hefei (China) and Univ. Heilbronn (Germany); G. Jun, Univ. of Technology, Hefei (China) and Institute of Intelligent Machines (China); P. Ott, Univ. Heilbronn (Germany); W. Lei, W. Xiaojia, Univ. of Technology, Hefei (China)

$65850 \mathrm{U}$ Absolute position sensor using Gaussian beam propagation properties and their spatial modulation [6585-33]

D. Haddad, Lab. national de métrologie et d'essais (France); P. Juncar, Conservatoire national des arts et métiers (France); G. Genevès, Lab. national de métrologie et d'essais (France); P. Pinot, Conservatoire national des arts et métiers (France)

65850V Temperature influence in confocal techniques for a silicon wafer testing [6585-34] D. Litwin, J. Galas, S. Sitarek, Institute of Applied Optics (Poland); B. Surma, B. Piatkowski, A. Miros, Institute of Electronics Materials Technology (Poland)

\section{SESSION 9 CHEMICAL SENSORS AND BIOSENSORS I}

65850W Analytical applications of aptamers (Invited Paper) [6585-35]

S. Tombelli, M. Minunni, M. Mascini, Univ. degli Studi di Firenze (Italy)

65850X Development of new $\mathrm{H}_{2}$ TPP porphyrin films with improved optical sensing capabilities [6585-36]

M. Tonezzer, Univ. of Trento (Italy) and LNL, INFN (Italy); G. Maggioni, LNL, INFN (Italy); K. Severova, Brno Univ. of Technology (Czech Republic); S. Carturan, LNL, INFN (Italy); A. Quaranta, Univ. of Trento (Italy); G. Della Mea, Univ. of Trento (Italy) and LNL, INFN (Italy)

$65850 \mathrm{Y}$ Optical principle of $\mathrm{pH}$ measurement for detection of auxin flow through cellular membrane [6585-37]

O. Podrazky, J. Mrazek, M. Seidl, I. Kasik, P. Tobiska, V. Matejec, T. Martan, J. Aubrecht, Institute of Photonics and Electronics (Czech Republic)

$65850 Z$ Preparation and characterization of transducer layers for opto-electrochemical detection of chlorine in water [6585-38]

I. Kasik, J. Mrazek, O. Podrazky, M. Seidl, P. Tobiska, V. Matejec, Institute of Photonics and Electronics (Czech Republic); B. Kovacs, A. Markovics, M. Szili, Univ. of Pecs (Hungary);

K. VIckova, CTU (Czech Republic) 


\section{SESSION 10 CHEMICAL SENSORS AND BIOSENSORS II}

658510 Carbon dioxide, oxygen, and pH detection in animal adipose tissue by means of extracorporeal microdialysis [6585-39]

F. Baldini, Institute for Applied Physics, CNR (Italy); A. Bizzarri, M. Cajlakovic, F. Feichtner, Joanneum Research (Austria); L. Gianesello, Univ. of Florence (Italy); A. Giannetti, Institute for Applied Physics, CNR (Italy); G. Gori, Univ. of Florence (Italy); C. Konrad, Joanneum Research (Austria); A. A. Mencaglia, Institute for Applied Physics, CNR (Italy); E. Mori, V. Pavoni, A. M. Perna, Univ. of Florence (Italy); C. Trono, Institute for Applied Physics, CNR (Italy)

658511 Microstructure fibers for sensing gaseous hydrocarbons [6585-40] V. Matejec, J. Mrazek, O. Podrazky, J. Kanka, I. Kasik, M. Pospisilova, Institute of Photonics and Electronics (Czech Republic)

658512 Hydrogen leak detection by means of fiber Bragg gratings covered by a catalytic sensitive layer [6585-41]

C. Caucheteur, Faculté Polytechnique de Mons (Belgium); M. Debliquy, D. Lahem, Materia Nova ASBL (Belgium); P. Mégret, Faculté Polytechnique de Mons (Belgium)

658513 ORMOSIL's layers as luminophores' matrices in an UV optical fibre's sensor [6585-42]

J. Rayss, E. M. Chodkowska, Maria Curie-Sklodowska Univ. (Poland); W. Czajkowski,

R. Stolarski, Technical Univ. of Lodz (Poland)

658514 Integrated fiber optical and thermal sensor for noninvasive monitoring of blood and human tissue [6585-43]

V. A. Saetchnikov, E. A. Tcherniavskaia, Belarusian State Univ. (Belarus); G. Schiffner, Ruhr

Univ. (Germany)

\section{SESSION 11 CHEMICAL SENSORS AND BIOSENSORS III}

658515 Novel polarization control for high-throughput surface plasmon resonance sensors [6585-44]

M. Piliarik, Institute of Photonics and Electronics (Czech Republic); J. Katainen, Univ. of Oulu

(Finland); J. Homola, Institute of Photonics and Electronics (Czech Republic)

658516 Photonics and microarray technology [6585-45]

E. Skovsen, M. Duroux, M. T. Neves-Petersen, L. Duroux, S. B. Petersen, Univ. of Aalborg (Denmark) and BioNanoPhotonics A/S (Denmark)

658517 Design and realization of highly stable porous silicon optical biosensor based on proteins from extremophiles [6585-46]

L. De Stefano, Institute for Microelectronics and Microsystems, CNR (Italy); L. Rotiroti, I. Rea, Institute for Microelectronics and Microsystems, CNR (Italy) and Federico II Univ. of Naples (Italy); E. De Tommasi, Institute for Microelectronics and Microsystems, CNR (Italy); A. Vitale, M. Rossi, Institute of Protein Biochemistry, CNR (Italy); I. Rendina, Institute for Microelectronics and Microsystems, CNR (Italy); S. D'Auria, Institute of Protein Biochemistry, CNR (Italy)

658518 Development of an inexpensive optical fiber based harmful algae bloom sensor [6585-47] E. O'Connell, Univ. of Limerick (Ireland); W. Lyons, City Univ. (United Kingdom); C. Sheridan, E. Lewis, Univ. of Limerick (Ireland) 
658519 Polymer optical sensor based on photochromic switching of charge carrier mobility [6585-48]

M. Weiter, M. Vala, O. Zmeškal, J. Navrátil, Brno Univ. of Technology (Czech Republic);

P. Toman, Institute of Macromolecular Chemistry (Czech Republic); S. Nešpưrek, Brno Univ. of Technology (Czech Republic) and Institute of Macromolecular Chemistry (Czech

Republic)

\section{POSTER SESSION}

$65851 \mathrm{~A}$ Analysis of the sensitivity of integrated nonlinear optical evanescent wave sensors [6585-50]

S. Taya, Islamic Univ. of Gaza (Palestinian Authority); M. M. Shabat, Max-Planck-Institut für Physik komplexer Systeme (Germany); M. M. Abadla, Alaqsa Univ. (Palestinian Authority); H. M. Khalil, Ain Shams Univ. (Egypt)

$65851 \mathrm{~B}$ Super-resolution for infrared beam profile measurement [6585-51]

U. H. P. Fischer-Hirschert, T. Windel, Harz Univ. of Applied Sciences (Germany); I. Zakharov,

D. Dovnar, ITM (Belarus)

65851C A position- and time-sensitive photon-counting detector with delay-line read-out [6585-52] O. Jagutzki, Univ. Frankfurt (Germany); V. Dangendorf, R. Lauck, Physikalisch-Technische Bundesanstalt (Germany); A. Czasch, Univ. Frankfurt (Germany); J. Milnes, Photek Ltd. (United Kingdom)

$65851 \mathrm{~F}$ Simultaneous liquid level and refractive index measurements with a POF-based sensor [6585-55]

S. Selleri, F. Poli, M. Foroni, A. Cucinotta, Univ. of Parma (Italy)

$65851 \mathrm{G}$ Short capillary tubing as fiber optic sensor of viscosity of liquids [6585-56]

M. Borecki, Warsaw Univ. of Technology (Poland); M. L. Korwin Pawlowski, Univ. du Québec en Outaouais (Canada); M. Bebłowska, A. Jakubowski, Warsaw Univ. of Technology (Poland)

$65851 \mathrm{H} \quad$ Refractive index sensitivity in thinned long period gratings [6585-57]

A. Iadicicco, Univ. of Naples Parthenope (Italy); G. Servodio, Univ. of Sannio (Italy); P. Pilla, Univ. of Sannio (Italy) and Institute of Composite Biomedical Materials, CNR (Italy): S. Campopiano, Univ. of Naples Parthenope (Italy); M. Giordano, Institute of Composite Biomedical Materials, CNR (Italy); A. Cutolo, A. Cusano, Univ. of Sannio (Italy)

658511 Reflection-type side-polished fiber submersion sensor using an optical fiber mirror in a manhole [6585-59]

C.-H. Lee, S. J. Park, M. S. Jeon, H. D. Kim, Kyungpook National Univ. (South Korea); J. Park, Keimyung Univ. (South Korea); J.-W. Song, Kyungpook National Univ. (South Korea)

$65851 \mathrm{~J}$ Superstructure fiber Bragg gratings with coated polyaniline film for ammonia detecting [6585-60]

L. Ai, National Defense Univ. (Taiwan); J.-C. Mau, W.-F. Liu, Feng-Chia Univ. (Taiwan);

M.-Y. Fu, Air Force Academy (Taiwan); T.-C. Chen, National Defense Univ. (Taiwan)

65851 K Fibre optic sensor with disturbance localization in one optical fibre [6585-61]

M. Życzkowski, W. Ciurapinski, Military Univ. of Technology (Poland) 
65851L Optoelectronic observation system with active illumination [6585-62]

M. Piszczek, K. Rutyna, M. Szustakowski, Military Univ. of Technology (Poland)

$65851 \mathrm{M}$ Room temperature detection of chemical pollutants by $\mathrm{SnO}_{2}$-based optical fiber sensors [6585-63]

M. Consales, M. Pisco, P. Pilla, A. Cutolo, Univ. of Sannio (Italy); A. Buosicolo, Univ. of Napoli (Italy); R. Viter, V. Smyntyna, Odessa National Univ. (Ukraine); M. Giordano, Institute of Composite Biomedical Materials, CNR (Italy); A. Cusano, Univ. of Sannio (Italy)

658510 Examination of bacteria drug resistance utilizing surface plasmon resonance [6585-65] Y.-L. Chiang, H.-F. Chen, C.-H. Lin, National Yang-Ming Univ. (Taiwan); S.-J. Chen, National Cheng-Kung Univ. (Taiwan)

65851P Depth sensitivity of magneto-optic Kerr effect on FeNbB amorphous ribbons [6585-66] O. Źivotsky, K. Postava, Technical University of Ostrava (Czech Republic); L. Kraus, Institute of Physics (Czech Republic); K. Hrabovská, J. Pištora, Technical University of Ostrava (Czech Republic)

65851Q A SiGe optical receiver with large-area photodiode [6585-67]

A. Marchlewski, W. Gaberl, H. Zimmermann, Vienna Univ. of Technology (Austria)

$65851 \mathrm{R}$ Study of optoelectronic $\mathrm{NO}_{2}$ detector using cavity enhanced absorption spectroscopy [6585-68]

A. Czyzewski, Institute of Applied Optics (Poland); J. Wojtas, Military Univ. of Technology (Poland); T. Stacewicz, Warsaw Univ. (Poland); Z. Bielecki, M. Nowakowski, Military Univ. of Technology (Poland)

$65851 \mathrm{~S}$ Nanostructured interfacial architectures for detection of biospecific interactions [6585-69] P. M. Boltovets, A. A. Savchenko, B. A. Snopok, V. Lashkaryov Institute of Semiconductor Physics (Ukraine)

$65851 \mathrm{~T}$ Soluble phthalocyanines as optical gas sensing materials [6585-70]

K. Severova, Brno Univ. of Technology (Czech Republic) and LNL, INFN (Italy); G. Maggioni, Univ. of Padua, LNL, INFN (Italy); S. Nespurek, Brno Univ. of Technology (Czech Republic) and Institute of Macromolecular Chemistry (Czech Republic); S. Carturan, Univ. of Padua, LNL, INFN (Italy); R. Milan, M. Tonezzer, LNL, INFN (Italy); G. Della Mea, LNL, INFN (Italy) and Univ. of Trento (Italy)

$65851 \mathrm{U}$ Mode visualization for fiber optic temperature sensor [6585-71]

V. Vasinek, P. Siska, L. Marsalek, J. Skapa, Technical Univ. Ostrava (Czech Republic)

$65851 \mathrm{~V}$ Bio-chemical sensor based on imperfected plastic optical fiber [6585-72]

A. Babchenko, V. Chernyak, J. Maryles, Jerusalem College of Technology (Israel)

$65851 \mathrm{~W}$ Measurements and modeling of birefringence in PMMA channel waveguides inscribed with DUV radiation [6585-73]

G. Golojuch, Wroclaw Univ. of Technology (Poland); U. Hollenbach, T. Mappes, J. Mohr, Forschungszentrum Karlsruhe GmbH (Germany); A. Urbanczyk, W. Urbanczyk, Wroclaw Univ. of Technology (Poland)

$65851 Y$ SPR sensor based on a bi-diffractive grating [6585-75]

P. Adam, J. Dostálek, O. Telezhnikova, J. Homola, Institute of Photonics and Electronics

(Czech Republic) 
658520 Performance of InAs-based infrared photodiodes [6585-77]

V. V. Tetyorkin, A. V. Sukach, S. V. Stary, V. Lashkaryev Institute of Semiconductor Physics (Ukraine); N. V. Zotova, S. A. Karandashev, B. A. Matveev, M. A. Remennyi, N. M. Stus', IOFfE Physico-Technical Institute (Russia)

658522 Diffraction grating-coupled surface plasmon resonance sensor based on spectroscopy of long-range and short-range surface plasmons [6585-79]

M. Vala, J. Dostálek, J. Homola, Institute of Photonics and Electronics (Czech Republic)

658524 Examination of propagation process of annular beam in random media [6585-81]

T. Shiina, Y. Tsuge, T. Honda, Chiba Univ. (Japan)

658525 Measurement of modulation transfer function of infrared optoelectronic detector [6585-82] L. Liu, B. Chen, Nanjing Univ. of Science and Technology (China)

658526 Optoelectronic sensors on GaSb- and InAs-based heterostructures for ecological monitoring and medical diagnostics [6585-83]

M. Mikhailova, N. Stoyanov, I. Andreev, B. Zhurtanov, S. Kizhaev, E. Kunitsyna, K. Salikhov,

Y. Yakovlev, Ioffe Physico-Technical Institute (Russia)

658527 Hollow fibres integrated with single walled carbon nanotubes as novel opto-chemical sensors [6585-84]

M. Pisco, M. Consales, A. Cutolo, Univ. of Sannio (Italy); M. Penza, P. Aversa, ENEA (Italy); S. Campopiano, Univ. of Naples, Parthenope (Italy); M. Giordano, Institute of Composite and Biomedical Materials, CNR (Italy); A. Cusano, Univ. of Sannio (Italy)

658528 InGaAsN MSM photodetectors using RF-sputtered ITO layers as transparent Schottky contacts [6585-85]

W. C. Chen, Y. K. Su, R. W. Chuang, H. C. Yu, B. Y. Chen, National Cheng Kung Univ. (Taiwan)

658529 Large dynamic range wavefront sensor based on a cylindrical microlens array [6585-86] M. Ares, S. Royo, Technical Univ. of Catalunya (Spain)

65852A Numerical simulation and optimisation of the fibre-optic sensors in Sagnac configuration by investigating their polarisation properties [6585-87]

L. R. Jaroszewicz, R. Świłło, Z. Krajewski, Military Univ. of Technology (Poland)

65852B Demodulator of phase signal for singlemode fiber-optics [6585-88]

I. Merta, L. R. Jaroszewicz, Military Univ. of Technology (Poland)

65852C Toward a hyperspectral optical signature of extra virgin olive oil [6585-89]

A. G. Mignani, L. Ciaccheri, IFAC, CNR (Italy); H. Thienpont, H. Ottevaere, Vrije Univ. Brussel (Belgium); C. Attilio, A. Cimato, IVALSA, CNR (Italy)

65852D Application of planar waveguides with gradient index profile to determine parameters of thin active layers used in waveguide sensors [6585-90]

E. Auguściuk, F. Sala, Warsaw Univ. of Technology (Poland)

$65852 \mathrm{G}$ Absolute method for an optical measurement of the earth gravitational axis: application to Watt balance [6585-21]

K. Ouedraogo, S. Topsu, L. Chassagne, Univ. of Versailles Saint-Quentin (France); P. Juncar, LNE-INM (France); J. Nasser, Y. Alayli, Univ. of Versailles Saint-Quentin (France)

Author Index 


\title{
Conference Committee
}

\author{
Symposium Chairs
}

Pavel Tománek, Brno University of Technology (Czech Republic)

Miroslav Hrabovský, Palacký University (Czech Republic)

Hugo Thienpont, Vrije Universiteit (Belgium)

Symposium Honorary Chair

Karel Jungwirth, Institute of Physics (Czech Republic)

Conference Chairs

Francesco Baldini, Institute for Applied Optics, CNR (Italy)

Jirí Homola, Institute of Photonics and Electronics (Czech Republic)

Robert A. Lieberman, Intelligent Optical Systems, Inc. (USA)

Conference Cochair

Miroslav Miler, Institute of Photonics and Electronics (Czech Republic)

Program Committee

Brian Culshaw, University of Strathclyde (United Kingdom)

John P. Dakin, University of Southampton (United Kingdom)

Artur Dybko, Warsaw University of Technology (Poland)

Nicole Jaffrezic-Renault, Ecole Central de Lyon (France)

Leszek R. Jaroszewicz, Military University of Technology (Poland)

Paul V. Lambeck, Universiteit Twente (Netherlands)

Aleksandra Lobnik, University of Maribor (Slovenia)

Vlastimil Matējec, Institute of Photonics and Electronics (Czech Republic)

Guillermo Orellana, Universidad Complutense (Spain)

Olivier M. Parriaux, Université Jean Monnet Saint-Etienne (France)

Reinhardt Willsch, Institute of Photonic Technology (Germany)

Andrius Zukauskas, Vilnius University (Lithuania)

\section{Session Chairs}

1 Components for Sensor Systems I

Jiří Homola, Institute of Photonics and Electronics (Czech Republic)

2 Components for Sensor Systems II

El-Hang Lee, Inha University (South Korea) 
3 Fibre Optic Sensors I

Robert A. Lieberman, Intelligent Optical Systems, Inc. (USA)

$4 \quad$ Fibre Optic Sensors II

Vlastimil Matējec, Institute of Photonics and Electronics (Czech Republic)

$5 \quad$ Interferometric Sensors

Miroslav Miler, Institute of Photonics and Electronics (Czech Republic)

$6 \quad$ Integrated Optical Sensors

Robert A. Lieberman, Intelligent Optical Systems, Inc. (USA)

$7 \quad$ Distributed Sensors and Sensor Networks

Reinhardt Willsch, Institute of Photonic Technology (Germany)

8 Free-Space Optic Sensors

Miroslav Miler, Institute of Photonics and Electronics (Czech Republic)

9 Chemical Sensors and Biosensors I

Francesco Baldini, Institute for Applied Optics, CNR (Italy)

10 Chemical Sensors and Biosensors II

Marco Mascini, University degli Studi di Firenze (Italy)

11 Chemical Sensors and Biosensors III

Jirí Homola, Institute of Photonics and Electronics (Czech Republic) 